de l'Afrique Noire s'est réuni et chaque commission a élaboré ses vœux qui, soumis à l'approbation de l'Assemblée Générale, devront être présentés aux pouvoirs publics.

\title{
Scientific Council for Africa South of the Sahara
}

THE establishment of a Scientific Council, to discuss how science can best be applied to the benefit and development of Africa, was recommended by the African Regional Conference held in Johannesburg in October 1949. The Council, which consists of thirteen eminent scientists qualified to speak with authority on the several branches of science of direct interest to Africa south of the Sahara, held its first meeting at Nairobi in November 1950. The Chairman of the Council is Dr. P. J. du Toit, President of the South African Council for Scientific and Industrial Research; the Vice-Chairman is Professor J. Millot, Director of the Scientific Institute, Madagascar; the Council includes members from Belgium, France, Portugal, Southern Rhodesia, South Africa, and the United Kingdom and Colonies. Arrangements have been made for a permanent secretariat, and Dr. E. B. Worthington, Scientific Secretary, East African High Commission, is the first Secretary-General. The functions of the Council are to recommend for study research problems of common interest; to maintain relations with existing and future inter-governmental scientific bureaux; to encourage contacts between research workers; to facilitate exchange and movement of scientific workers between different territories; to collect and distribute reports and information; to suggest and facilitate the convening of scientific conferences and meetings of specialists.

\section{Une représentation théâtrale au Rwanda}

Pour célébrer le cinquantième anniversaire du premier contact entre la civilisation occidentale et leur culture, les Banyarwanda ont organisé à Astrida trois jours de festivités. Les Pères Blancs ont joué un rôle important dans ces manifestations et l'un d'eux, le R.P. Weymeersch, a conçu et réalisé un jeu scénique qui fut une réussite temarquable. Ce jeu scénique, qui procédait de la tradition des Mystères du Moyen Âge, avait pour sujet l'histoire du monde et de $R$ wanda du point de vue chrétien. Il a compris trois parties : la création et la chute, la rédemption par le Christ, la christianisation du monde et du Rwanda. Le spectacle eut lieu le soir en plein air; la scène immense a permis des épisodes simultanés et l'emploi de quatre cents figurants. La musique provenait de deux sources: des enregistrements de musique européenne, choisis par le R.P. Weymeersch; de plus, un chour dirigé pat le R.P. Seumois exécuta de la musique religieuse et des chants indigènes. Chantres et acteurs étaient tous Africains, élèves des principales écoles du Rwanda. Le texte était en kinyarwanda, un commentaire en français étant diffusé pour les spectateurs européens. Les acteurs ne se tenaient pas au texte rédigé par le R.P. Weymeersch; celui-ci leur avait laissé la faculté d'interpréter leur rôle de façon personnelle. Les Pères Blancs espèrent que le jeu d'Astrida incitera les Banyarwanda à créer un théâtre autochtone.

\section{Gladstone Llewselyn Letele}

THE death in September 1950 of G. L. Letele cut short a distinguished career full of promise for the future. Dr. Letele was already well known as a linguist and teacher, and his colleagues had hopes of further successes for him in the field of African language study. After graduating at Fort Hare, Mr. Letele served for a time on the staff of Adams College, Natal, and in 1939 was admitted to the School of African Studies at the University of Cape Town, where he studied African and European languages and qualified for the degree of Master of Arts. In I94I he joined the staff at Fort Hare as lecturer in Sotho and Tswana; in 1947 he came to 